\title{
Contracting Out Public Services to NGo Practices in ASIAN COUNTRIES
}

\author{
Dodik Setiawan Nur Heriyanto
}

\begin{abstract}
In Asian countries, contracting out public services to NonGovernmental Organization (NGO) has been recognized as usual practice to support government function. This study found that their contractual agreement with the government strikes the nature of NGO as self-governing institutions, non-profit orientation, and independency.
\end{abstract}

Keywords: NGO, public services, Asian Countries

\section{Introduction}

The term of "Non-Governmental Organization" or generally abbreviated as NGO has been firstly recognized as universal designation for private and independent organizations working for non-profit outcomes since the enactment of the United Nations Charter $1945 .{ }^{1}$ Up to present, the works of NGO are diverse in many areas not only limited with their involvement in the United Nation's forum. They even play an essential role in social and economic development of a state.

Activities of NGO must be independent from any government's influence. They shall not work for political and commercial advantages. Yet, since there has no basic boundaries of their structure and role, many NGOs work to carry out government functions and it has been practiced in some Asian countries like China, Pakistan, Cambodia, and Indonesia. Unfortunately, contracting out certain public services to NGO challenge their nature as independent organization.

\section{Relationship between Government and NGO (Practice in Asian Countries)}

The nature of NGO activities is basically neither operating by government nor driven by profit goals. With this characteristics, most scholars agree to

\footnotetext{
Dodik Setiawan Nur Heriyanto, PhD candidate at Faculty of Law, University of Debrecen and Lecturer at Faculty of Law, Islamic University of Indonesia.

E-mail: dodiksetiawan@uii.ac.id

${ }^{1}$ See article 71 the United Nations Charter 1945. In the charter, the term of 'NGO' is actually to differentiate with the term "specialized agencies" as organizations with varying degrees of independence that agree to coordinate their work through agreements with ECOSOC.
} 
personalized them as 'the agent of development ${ }^{2}$ to fix the problems that have befallen the development process (Edwards \& Hulme (eds.), 1996, 3.). Because of refusing government influence (Fisher, 1997), NGOs have distinct mind sets and attitudes that lead them to be more flexible in tackling multi sector issues of development with the grass-root movement or even direct actions that have an impact upon government policy-making. Their voice which usually speaking out against the government policy also have legitimacy in the eyes of public. Public legitimacy, the greater source of NGOs spirit to survive, naturally exists from their pure mission to stand up with public interests.

In the developing world, NGOs are also often in partnership along with the government working to increase development through different channels and activities. Their opposing position against deviate policy of the government indeed reflects the balancing effort for true democracy. However, in certain circumstances NGO substitutes state presence in protecting social rights and other vulnerable segments such as reducing carbon emission, protecting wild animal, peace building mission, and etc. A good cooperation between NGOs and government is potential motivation to increase the development of state while the NGOs fill the gap on the government's failure to target major societal problems.

Generally, a state has obligation to provide public services to the society but sometimes their services could not reach effectively to the society because of common bureaucracy obstacles (such as less productivity, financial constraint (inefficient), and lack of qualified governance). This study found that in some Asian countries, contracting out public services to NGO has been practiced as preferential tool to reach the public sector objectives. In Pakistan, the lack of government capability to provide healthcare services is the leading ground of the government to outsource the administration of primary health care services to NGOs. The contracted NGOs to carry out public health care services in the district of Rahim Yar Khan demonstrate their ability to improve the utilization of the existing Basic Health Units (BHU), physical conditions, availability of drugs, and staff punctuality (World Bank, 2006; Tanzil - Zahidie - Ahsan - Kazi - Shaikh, 2014, 277.).

Since 1990 contracting out social services to NGOs has been carried out by local governments in China mostly in urban areas (Shanghai, Beijing, Guangzhou, and Shenzhen) (Xijin \& Ming, 2009, 6.). The Purchase of Service Contracting (扩大购买服务 - kuodagoumaifuwu) has been increasingly applied to meet demands of public services including education, public health, elderly services, handicapped services, community services, employment, city planning, as well as cultural activities (Chan, 2015, 10.; Teets, 2012, 17-20.) that shifting the role of the government in public services from being a direct provider to a public resources coordinator. For instance,

\footnotetext{
${ }^{2}$ Some scholars also specified NGOs as agents of the democratization. See Clark, J. (1991), Democratising Development: The Role of Voluntary Organizations. Earthscan, London. 1991, p. 5.; Fowler, A. (1993), NGOs as Agents of Democratization: An African Perspective. Journal of International Development. 1993, 5 (3); Jenny Pearce views NGOs as facilitators of development process rather than as agents of change. See Pearce, J. (1993), NGOs and Social Change: Agents or Facilitators? Development in Practice. 1993, 3 (3), p. 224.
} 
in Shanghai, NGOs are performing as the operator of socialized elder care affairs and the performer of community elder server while at the same time the local government is acting as policy maker, service designer, public financial supporter, and public elder services buyer (Yu, 2014, 156.).

Having position as the poorest and least healthy countries in Southeast Asia (Jacobs \& Price, 2006, 27-39.; Levine \& Gardner, 2008, 1.), to increase the access of affordable health care starting 1998 Cambodia tendered management of government health services to NGOs (Deolalikar ShikhaJha - Quising, 2015, 170.). Moreover, funded by the Asian Development Bank and the World Bank, Cambodia established a pilot policy 'Contracting of Health Service Project' undertaken between 1999 to 2003 to provide district health services in selected districts that encompassed 1.26 million populations (Bhushan - Keller - Schwartz, 2002, 1-3.). A study conducted by Jarrah (2008) found health centres that contracted out by NGOs were achieved a higher percentage of the catchment population's need. In addition, she also argued that contracted health centres, whether located in rural or urban areas, performed better than the non-contracted government facilities.

\section{Dilemmas in Contracting Out Public Services to NGOs}

As previously discussed, we do understand that contracting out public services to NGO provides greater advantages and effective achievements. ${ }^{3}$ However, tendering public services to NGOs through a contractual agreement will result legal dilemmas that undermine the nature of NGO. This contractual agreement has no profit gain but in fact threatening their independency. In water service contract practices, for instance, NGO is under pressure with the contractual requirements. The pressure is on NGOs to become increasingly commercial in order to implement their contracts efficiently (Clayton, 1999, 20.). ${ }^{4}$ The position of NGO in doing such commercial activities would question their position as voluntary organization. The output of contracting out to deliver certain services to NGOs would make them prefer to reach quantitative requirements under the contract than the qualitative objectives of their mission to increase community development.

It must be noted that Government Organized NGO (GONGO) in China is absolutely not independent (Beja, 2006, 53-74.) because they are formed by the government or Communist Party Organizations (Brothers, 2015, 53-74). The Chinese government also extend their control to NGOs created by individuals dissociate from government or party organization (Ma, 2002, 113-130.). In practice the Government prefer to tender their public services to GONGO than the private NGO under the reason of easy to control their activities but a study (Chan, 2010, 301-306.; Kang \& Heng, 2008, 50-55.) found that GONGO has lower control from the government than the other

\footnotetext{
${ }^{3}$ For example: conflict and disaster situation.

4 In water service contracts practice, NGO is under pressure with the contractual requirements. The pressure is on NGOs to become increasingly commercial in order to implement their contracts efficiently.
} 
kinds of NGO (see table 1 below). Though their activities are getting less control from the government, GONGO itself usually acknowledged as the puppet of the government that could be spared from ethical standards of bureaucracy just because to follow the order of the government.

In general, the tight control over NGOs in China presumably endangers NGO work as independent organization. Particularly the high level control for certain NGOs working in sensitive areas will pressure them to limit their work (Schwartz, 2004, 40-45.) in accordance with the authoritarian government political goals.

Table 1

Graduated Control of NGOs in China [Wu, F. \& Chan, K. M. (2012), 917.]

\begin{tabular}{|c|c|c|c|}
\hline Business Nature & $\begin{array}{ll}\text { Main } & \text { Funding } \\
\text { Sources } & \\
\end{array}$ & Scale & Level of Control \\
\hline \multirow{2}{*}{$\begin{array}{l}\text { Category I: } \\
\text { service delivery }\end{array}$} & \multirow{2}{*}{$\begin{array}{l}\text { Government, } \\
\text { GONGO, official } \\
\text { foundations }\end{array}$} & $\begin{array}{l}\text { Small NGO based } \\
\text { in residential } \\
\text { community }\end{array}$ & Low \\
\hline & & $\begin{array}{l}\text { Medium to large } \\
\text { NGO, across } \\
\text { communities }\end{array}$ & Medium \\
\hline \multirow{2}{*}{$\begin{array}{l}\text { Category II: } \\
\text { service, } \\
\text { outreach, public } \\
\text { advocacy in non- } \\
\text { sensitive areas }\end{array}$} & $\begin{array}{l}\text { Domestic enterprises, } \\
\text { domestic private } \\
\text { foundations }\end{array}$ & \multirow{2}{*}{$\begin{array}{l}\text { NGO and/or cross- } \\
\text { regional network }\end{array}$} & Low to Medium \\
\hline & $\begin{array}{lll}\begin{array}{l}\text { Foreign } \\
\text { funding }\end{array} & \\
\end{array}$ & & Medium to High \\
\hline $\begin{array}{l}\text { Category III: } \\
\text { advocacy in } \\
\text { political/religious/ } \\
\text { ethnic and/or other } \\
\text { sensitive areas }\end{array}$ & $\begin{array}{l}\text { Private donations, } \\
\text { international NGO, } \\
\text { and foundations }\end{array}$ & $\begin{array}{l}\text { NGO, } \\
\text { groups, } \\
\text { network }\end{array}$ & High \\
\hline
\end{tabular}

The successful experience of contracting out health care services to NGO in Cambodia and Pakistan also increased the public transaction cost to the government when compared to the direct public services. Understanding that staff motivation as the key challenge it needed to overcome, the NGO contractors applied additional salary and performance-based incentives for their staff (Bloom et. al., 2006, 11.). The government in fact must also allocate time to directly monitor the performance of contracted NGOs and ensure the delivery of public services in an efficient, effective, and fair manner. Thus, contracting generates higher cost and time consuming to the government which usually serve as huge burden for developing and least developed countries.

Indonesian practice on government-NGO relationship seems reliable and closed to the ideal concept. Under the Indonesian law, NGO has an important place to support government role to provide public services to its citizens. ${ }^{5}$ Noting that contracting out such services will lead to higher cost and time consuming thus partnership between NGO and government

\footnotetext{
${ }^{5}$ Act No. 32 Year 2004 about Local Government, article 195.
} 
provider services work together under the 'Memorandum of Understanding' (MoU) which is not legally binding between them but giving guidance the role and function of NGO in the service delivery. For instance, MoU between local health provider and MoU usually positioned NGO as the controlling party to supervise the delivery service not as the direct provider. In natural disaster or armed conflict situation, NGO has possibility to be contracted by the government to provide public services but only in short period to recover such crisis situation while the government has lack human and financial resources. ${ }^{6}$

\section{Conclusion}

Contracting out public services to NGO has been raised many critics in particular about their independency. This study found that even though in Pakistan and Cambodian practice of contracting generates advantages in certain areas but the cost of service delivery is higher than the direct service expenses. Additionally, NGO is under pressure under the public contract to become increasingly commercial in order to implement their contract efficiently.

With contracting or not, the Chinese government has been established the tight control over the NGOs that presumably strikes NGOs work as independent organization. Preferring tender public services to GONGO, as commonly refer as the puppet of the government; keep them at the distance of democratic values.

Indonesia has a distinct practice of contracting public services to NGO that only applied in crisis situation and short period of contracting. Though partnership between NGO and government guaranteed by the Indonesian law but the substance of contracting is not to make them to be service provider, merely as controller of service delivery. Aware with the cost of contracting, the Indonesian government prefer to enter into Memorandum of Understanding with NGOs, which creates certain guideline of functions but has no financial and legal obligation.

List of References:

Act No. 32 Year 2004 about Local Government

Beja, J. P. (2006), The Changing Aspects of Civil Society in China. Social Research, 2006, 73 (1), pp. 53-74.

Bhushan, I. - Keller, S. - Schwartz, B. (2002), Achieving the Twin Objectives of Efficiency and Equity: Contracting Health Services in Cambodia. ERD Policy Brief Series No. 6, Asian Development Bank, Manila. 2002, pp. 1-3.

Bloom, E. et. al. (2006), Contracting for Health: Evidence from Cambodia. Brookings Institution, Washington. 2006, p. 11.

\footnotetext{
${ }^{6}$ For example, in Tsunami disaster in Aceh (2004), Merapi Eruption in Yogyakarta (1994 and 2014), and internal humanitarian conflict in Poso (1998-2001).
} 
Brothers, J. (2015), Rebalancing Public Partnership: Innovative Practice Between Government and Nonprofits Around the World. Burlington, Growing Publishing Company. 2015, pp. 174-178.

Chan, C. K. (2015), Rebuilding a Welfare System for China's Mixed Economy. In Ngok, K. \& Chan. C. K. (eds.), China's Social Policy: Transformation and Challenges. Routledge, New York. 2015, p. 10.

Chan, K. M. (2010), Commentary on Hsu: Graduated Control and NGO responses - Civil Society as Institutional Logic. Journal of Civil Society. 2010, 6 (3), pp. 301-306.

Clark, J. (1991), Democratising Development: The Role of Voluntary Organizations. Earthscan, London. 1991, p. 5.

Clayton, A. (1999). Contracts or Partnerships: Working through Local NGOs in Ghana and Nepal. Water Aid, London. 1999, p. 20.

Deolalikar, A. B. - ShikhaJha - Quising, P. F. (2015), Governance in Developing Asia: Public Service Delivery and Empowerment. Cheltenham - Northampton, Edward Elgar Publishing. 2015, p. 170.

Edwards, M. \& Hulme, D. (eds.) (1996), Beyond the Magic Bullet: NGO Performance and Accountability in the Post Cold War World. Kumarian, Hartford. 1996, p. 3.

Fisher, W. F. (1997), Doing Good? The Politics and Antipolitics of NGO Practices. Annual Review of Anthropology, 1997, 26 (1), pp. 439442.

Fowler, A. (1993), NGOs as Agents of Democratization: An African Perspective. Journal of International Development. 1993, 5 (3)

Jacobs, B. \& Price, N. (2006), Improving Access for the Poorest to Public Sector Health Services: Insights from Kirivong Operational Health District in Cambodia. Health Policy and Planning. 2006, 21, pp. 27-39.

Kang, X. \& Heng, H. (2008), Graduated Control: The State Society Relationship in Contemporary China. Modern China. 2008, 30 (1), pp. 50-55.

Levine, D. I. \& Gardner, R. (2008), Health Care in Cambodia. Briefing Paper, University of California, Berkeley. 2008, p. 1.

Ma, Q. (2002), Defining Chinese Nongovernmental Organizations. Voluntas: International Journal of Voluntary and Nonprofit Organizations. 2002, 13 (2), pp. 113-130.

Pearce, J. (1993), NGOs and Social Change: Agents or Facilitators? Development in Practice. 1993, 3 (3), p. 224.

Schwartz, J. (2004), Environmental NGOs in China: Roles and Limits. Pacific Affairs. 2004, 77 (1), pp. 40-45.

Tanzil, S. - Zahidie, A. - Ahsan, A. - Kazi, A. - Shaikh, B.T. (2014), A Case Study of Outsourced Primary Healthcare Services in Sindh, Pakistan: Is this A Real Reform? BMC Health Services Research. 2014, 14 p. 277.

Teets, J. (2012), Reforming Service Delivery in China: The Emergence of a Social Innovation Model. Journal of Chinese Political Science. 2012, 17, pp. 17-20.

United Nations Charter 1945

World Bank, (2006), Partnering with NGOs to Strengthen Management: An External Evaluation of the Chief Minister's Initiative on Primary 
Health Care in Rahim Yar Khan District, Punjab. South Asia Human Development Sector, Islamabad. 2006.

Wu, F. \& Chan, K. M. (2012), Graduated Control and Beyond: The Evolving Government-NGO Relations. China Perspectives, 2012, 3 pp.9-17.

Xijin, J \& Ming, S. (2009), Final Report on Government Procurement of Public Services People's Republic of China. Asian Development Bank. June 2009, p. 6.

$\mathrm{Yu}$, K. (2014), Diverse Participation and Orderly Guiding: The Establishment Policy strategies of the Community Socialized Elder Care Service System in Shanghai, China. Open Journal of Social Sciences. 2014, 2, p. 156. 